\title{
AN ANALYSIS OF THE TERMINOLOGY OF CONCEPTS OF COMPETITIVENESS IN THE PRESENTATIONS OF STRATEGIC DEVELOPMENT OF SELECTED CAR MANUFACTURERS
}

\section{Robert Zich}

\begin{abstract}
The primary objective of the presented research represents an evaluation of the terminology applied to the presentation of the strategic plans of companies. The purpose of the research was both an evaluation of the applicability of the terminology, defined in the theoretical level in the context of company practice, and - in a wider context - a search for links among the used approach of presentation, terminology and factual behavior of companies. The results show five key findings. First, the terminologies defined on the basis of the analysis of the three concepts of competitiveness share crucial common features. Second, the approach of the presentation used by the evaluated companies is still being developed, and reflects both external influences and internal aspects. Third, the manner used by the analyzed car producers is a rather significant element of its competitive behavior and, in a certain range, such a manner reflects the approach to the strategic development of competitiveness. Fourth, companies on a similar level of development tend to use similar way of communication. Fifth, the period of the economic crisis had less of a significant impact on the development of the communication of a company generally evaluated as less successful.
\end{abstract}

\section{Key words}

Competitiveness, competitive advantage, core competence, resource-based view, strategy, success-ability

\section{Introduction}

The presented results constitute the part of long-term research activity focusing on the approach of companies to strategic development of competitiveness with the application of the principles of a success-ability concept. The primary objective of the said research has been the identification and evaluation of approaches of companies to the strategic development of competitiveness. The part of research, presented in this article, represents a specific partial part, aiming at terminology applied to the presentation of the strategic plans of the evaluated companies. The submitted conclusions have been formulated within the framework of the research entitled "Determinants of Development of Management and Marketing in the Context of Transforming European Union" undertaken in the Faculty of Business and Management of Brno University of Technology in 2013 and 2014. The purpose of the evaluation of the presentation of the approach to the strategic development of the investigated companies was both the evaluation of the applicability of terminology, defined in the theoretical level in the context of company practice, and - in a wider context - the search for links among the used approach of presentation, terminology and factual behavior of companies. For the purposes of this research, as a presentation of the approach to strategic development there was considered the way used by companies to present their strategic behavior, their plans and approach 
to their markets. The research was focused on three selected car producers, resp. groups, i.e., Volkswagen Group, Renault Group and BMW Group. The research of the behavior of car producers has been conducted since 2010 till 2014. The subject of research has been formulated as an approach used by selected companies to present their strategic plans in connection to key subjects/key terms, determined on the basis of the analysis of selected concepts of competitiveness. The research questions have been framed as follows:

- How intensively are included the key subjects/terms related to the strategic development of competitiveness in the investigated documents?

- Can there be identified any changes in the approach used by companies to present such subjects/terms in the monitored period?

- Are there any differences among the investigated companies from the viewpoint of the use of identified key subjects/terms?

The first research question has been involved in the issue whether a certain pattern of use of specific terms may be identified in the presentation of a particular area. The second research question has identified changes in the monitored time period. The influence of the crisis years (2009 and 2010) has been particularly studied further to a general review made in the context of a time axis. The third research question has aimed at the evaluation of differences among individual companies, especially in the context of the link of evaluated areas. One fact may be anticipated, i.e., that each of the investigated companies has shown various levels of success in relation to the fulfillment of objectives and methods of their own development.

\section{Theoretical Framework}

The theoretical framework of the research includes three conceptions. Core competence conception and resource-based view (RBV) represent the outlining approaches from the viewpoint of the evaluated terminology and the logic of the interconnection of terms. The success-ability conception is then used especially from the viewpoint of the logic of the interconnection of factors. The core competence conception, as well as the interpretation based on resources, operates with several key terms. Besides the term "competence" it is used mainly with the terms assets, resources and capabilities, resp. so-called organizational capabilities. The basic starting point may be found in the work of Penrose, who perceives each company as unique, and its uniqueness results from a differentiation of resources and their use (Augier, 2007). Prahalad and Hamel understand each company not only as a portfolio of products or services, but also as a portfolio of competences. These authors link the identification of core competences with the fact that the said core competences contribute to the competitiveness of more products and services, overlap the framework of an individual product or service or - as the case may be - an industry in one company (Hamel, 2007). Similarly, Toni and Tonchia emphasize that core competences must enable potential use in many markets, must be perceived by a final consumer as the basic sources of added value and their imitation by competitors must be hard (De Toni, 2003). Collis and Montgomery from identify three categories of resources - tangible assets, intangible assets and organizational capabilities. From the viewpoint of competitive advantage Collis and Montgomery recognize the major significance just in the field of intangible assets and organizational capabilities. Intangible assets and organizational capabilities play their important roles from the viewpoint of competitive advantage and company value (Collis, 1997). Hitt clearly operates with the mutual interconnection 
of the above-mentioned terms and states that resources, capabilities and core competences form the basis of competitive advantage. Grant emphasizes that the differentiation between resources and company capabilities is essential. Grant understands resources as productive assets/property, owned by a particular company. Capabilities mean what such a company is able to do, or, in other words, "the ability to use resources to achieve the required final result". Individual resources themselves do not give competitive advantage, but such resources must "co-operate" to form a company's capability. Capability is the basis of excellent performance (Hitt, 2004). Apart from approaches which intentionally do not distinguish the terms property and resources, approaches considering such facts as important can be classified as regards the definition of basic terms: e.g., Freiling disagrees with the interpretation of resources as "a resource is anything which can be considered as the strength or weakness of a company". Freiling consistently uses the term assets/property, resources and competence (Freiling, 2004).

The significance of differentiation in the above-mentioned terms is obvious in connection with the evaluation of their role in the formation of competitive advantage. Hamel and Prahalad analyze the relationship of core competencies and competitive advantages in greater detail. Core competence is a resource of competitive advantage provided that such a core competence is competitively unique and brings some value to customers. Core competencies are a resource of competitive advantage, but not every competitive advantage represents a core competence. In this context, core competence can be understood as a certain qualification. Nevertheless, Collis assumes that in certain industries tangible and intangible assets can reasonably explain the formation of sustainable competitive advantage (Collis, 1994). Hitt formulates the process of internal analysis, which should lead to the identification of competitive advantage, resp. strategic competitiveness, within the framework of which Hitt specifies a certain logical sequence of resources, capabilities and competitive advantage (Hitt, 2004). Grant uses a similar principle to find out links between resources, capabilities and competitive advantage (Grant, 2008). From the viewpoint of the development of competences some authors operate with the term dynamic capability, resp. competence, or - as the case may be - dynamic concept based on capabilities (e.g. Augier, 2007; De Toni, 2003, Hitt, 2011; Mintzberg, 1967; Prieto, 2009; Salunke, 2011; Zhan, 2008). This concept emphasizes the ability of a company to form and develop its competences.

Despite the fact that the concept based on resources and core competences to a certain extent share a common terminology base, many differences in the logic of both approaches may be identified beyond their common characteristics. For example, Freiling presents an in-depth comparison of both concepts. Freiling identifies common elements in particular in a common base used for the explanation of the uniqueness of each company, with an emphasis on company strengths. As regards differences, according to Freiling, RBV assumes that company A is more successful than company B, provided that company A controls its resources more efficiently, or controls more effective resources, compared to company B. A view which takes into account competences goes one step further (as he stresses) and assumes that company A may be more successful than company B, provided that company A is in the position to enable the utilization of the available resources more efficiently or effectively compared to company B. Such a fact relates to the availability and use of competences which cannot be quickly imitated or substituted by competitors. Freiling identifies the key difference between RBV and the competence view in the causal chain. RBV estimates that extraordinary resources shall make the differences in the performance of companies. The concept of competences has more profound 
justification. Homogenous assets and heterogeneous resources represent a starting point of the chain. However, preconditions resulting from resources do not formulate an adequate explanation of efficiency differences. The company as such must be in a position facilitating the use of such resources in compliance with objective and market orientation. This is only possible supposing that there are competences enabling the company to use such resources. Competences develop the potential of resources and enable a company to adapt to the requirements of market immediately and non-randomly. Competences fill in the gap in the explanation of the relation of resources and performance by taking into consideration the flow of property/ assets and activities (Freiling, 2004).

The success-ability conception represents an approach to the strategic development of the competitiveness of the company based on target orientation, development of resources as a basis of competitive advantage and the need to define the position of the company within the environment in which such a company operates. Success-ability is formulated as the capability to reach - under particular conditions - objectives formulated in advance at the required level with the required level of development. From the viewpoint of competitiveness and competitive advantages, the mentioned conception works with three types of competitive advantages - purely competitive advantages, semi-competitive advantages and pseudo-competitive advantages. A determining factor, distinguishing which group a certain advantage belongs to, is the way of its formation, acquisition, development and maintenance within the framework of the so-called product or resource competitive triangle. In the case of a product competitive triangle we talk about the area of relations "company - customer- competitor", in the case of a resource competitive triangle "company- supplier- competitor". Such interpretation of triangles is connected with a specific understanding of the competitive environment and competition. Common terminology characteristics shared with concepts of a resource-based view and core competence may be identified especially in purely competitive advantages. Purely competitive advantages are linked with resources and their use. Success-ability conception uses four groups of resources - tangible, intangible, human resources and capabilities. Of course, these resources may establish core competences. Within the framework of the success-ability concept, each of these factors may be considered as the source of potential competitive advantage, either independently or in mutual combination (Zich, 2009, 2010, 2012).

\section{Methodology and Research Focus}

The research has been exploring the presentation of strategic development in four evaluated areas of selected companies. These evaluated areas have been the strategic development of competitiveness, the identification of competition and market, the characteristic of co-operation and partnership relations, the general characteristic of strategy and strategic objectives. The approach, connecting a.m. four areas, is perceived as a fundamental characteristic feature of each company. For the purpose of the research the individual areas are identified in compliance with the above-mentioned theoretical starting points - competitiveness, competition, cooperation and strategic objectives - see table 1. In the area of strategic development of competitiveness the analyzed terms have been defined especially on the basis of the above-mentioned analysis of the theoretical starting points of the concepts of resource-based view and core competence. The individual terms have been identified similarly in the remaining three areas in connection to the success-ability conception. To visualize the results the individual terms have been classified into the groups marked as overall intermediate term - see Table 1 . 


\begin{tabular}{|c|c|c|c|c|c|c|c|}
\hline \multicolumn{2}{|c|}{$\begin{array}{l}\text { Evaluated area } 1 \\
\text { Competitiveness }\end{array}$} & \multicolumn{2}{|c|}{$\begin{array}{l}\text { Evaluated area } 2 \\
\text { Competition }\end{array}$} & \multicolumn{2}{|c|}{\begin{tabular}{|l|} 
Evaluated area 3 \\
Cooperation
\end{tabular}} & \multicolumn{2}{|c|}{\begin{tabular}{|l|} 
Evaluated area 4 \\
Strategic objectives
\end{tabular}} \\
\hline $\begin{array}{l}\text { Overall } \\
\text { intermediate } \\
\text { terms }\end{array}$ & Terms & \begin{tabular}{|l|} 
Overall \\
intermediate \\
terms
\end{tabular} & Terms & \begin{tabular}{|l|} 
Overall \\
intermediate \\
terms
\end{tabular} & Terms & \begin{tabular}{|l|} 
Overall \\
intermediate \\
terms
\end{tabular} & Terms \\
\hline \multirow[t]{2}{*}{ Ability } & ability & \multirow{6}{*}{ Compete } & compete & \multirow{4}{*}{ Cooperation } & cooperation & Business model & business model \\
\hline & able & & competing & & cooperative & \multirow[t]{2}{*}{ Goal } & goal \\
\hline \multirow[t]{2}{*}{ Advantage } & advantage & & competition & & cooperating & & goals \\
\hline & \begin{tabular}{|l|} 
advantages \\
\end{tabular} & & \begin{tabular}{|l|} 
competitor \\
\end{tabular} & & \begin{tabular}{|l|} 
cooperate \\
\end{tabular} & \multirow[t]{2}{*}{ Idea } & idea \\
\hline \multirow[t]{5}{*}{ Capability } & capability & & competitors & \multirow[t]{7}{*}{ Partner } & partner & & ideas \\
\hline & capabilities & & competed & & \begin{tabular}{|l|} 
partner's \\
\end{tabular} & Mission & \begin{tabular}{|l|} 
mission \\
\end{tabular} \\
\hline & \begin{tabular}{|l|} 
capable \\
\end{tabular} & \multirow{5}{*}{ Market } & market & & partnered & \multirow[t]{2}{*}{ Objective } & $\begin{array}{l}\text { objective } \\
\end{array}$ \\
\hline & \begin{tabular}{|l} 
capacity \\
\end{tabular} & & \begin{tabular}{|l|} 
marketed \\
\end{tabular} & & partners & & objectives \\
\hline & \begin{tabular}{|l} 
capacities \\
\end{tabular} & & \begin{tabular}{|l} 
markets \\
\end{tabular} & & partnership & \multirow[t]{4}{*}{ Strategy } & \begin{tabular}{|l} 
strategy \\
\end{tabular} \\
\hline \multirow[t]{3}{*}{ Competence } & competence & & \begin{tabular}{|l} 
market's \\
\end{tabular} & & partnerships & & \begin{tabular}{|l|} 
strategies \\
\end{tabular} \\
\hline & competencies & & marketplace & & partnering & & strategic \\
\hline & \begin{tabular}{|l|} 
competency \\
\end{tabular} & & & \multirow[t]{6}{*}{ Supply } & supply & & strategically \\
\hline \multirow[t]{3}{*}{ Competitive } & competitiveness & & & & \begin{tabular}{|l} 
supplies \\
\end{tabular} & Success & success \\
\hline & competitive & & & & supplying & & successes \\
\hline & \begin{tabular}{|l|} 
competitively \\
\end{tabular} & & & & \begin{tabular}{|l} 
supplier \\
\end{tabular} & & successful \\
\hline Core & core & & & & \begin{tabular}{|l|} 
suppliers \\
\end{tabular} & & successfully \\
\hline \multirow[t]{5}{*}{ Strength } & \begin{tabular}{|l} 
strength \\
\end{tabular} & & & & supplied & & succeed \\
\hline & \begin{tabular}{|l|} 
strengthen \\
\end{tabular} & & & & & \multirow[t]{4}{*}{ Target } & target \\
\hline & strengthened & & & & & & targets \\
\hline & strengthening & & & & & & targeting \\
\hline & \begin{tabular}{|l|} 
strengths \\
\end{tabular} & & & & & & targeted \\
\hline & & & & & & ision & vision \\
\hline
\end{tabular}

Tab. 1: Key Topics of Content Analysis of Annual Reports of Evaluated Companies (Author)

Annual reports prepared by the evaluated car producers and published in the years 2000 through 2012 have represented the source of information for the evaluation and comparison of company behavior. Software Concordance version 3.3 and MS Excel 2007 have been used for the content analysis itself. A comparison of the absolute frequency of the occurrence of the terms has not been the aim of the evaluation and, in particular, the comparison of the individual groups. Such a type of comparison would be rather misleading considering the various scope of the annual reports compared. The percentage shares, identified below, express the number of percents by which a given overall intermediate term participates in the specification of the approach of a particular car producer to presentation in the individual evaluated areas; $100 \%$ is formed by the occurrence of all the searched terms.

\section{Development of the Presentation of Selected Aspects of Competitiveness in the Period from 2000 until 2012}

Certain similarity in the behavior of German groups is rather evident based on the comparison of the scope of the use of terms connected with the identification of competitiveness. Such similarity is strong especially in summarizing the evaluation for the whole period - see graphs in figure 1. A strong emphasis put on four terms - "ability", "capability", "competitive" and "strength" is common for all three groups. Rather interesting is the gradual significant growth of the popularity of the term "capability" in the period 2003 to 2012 in Renault Group. 


\section{Renault Group}

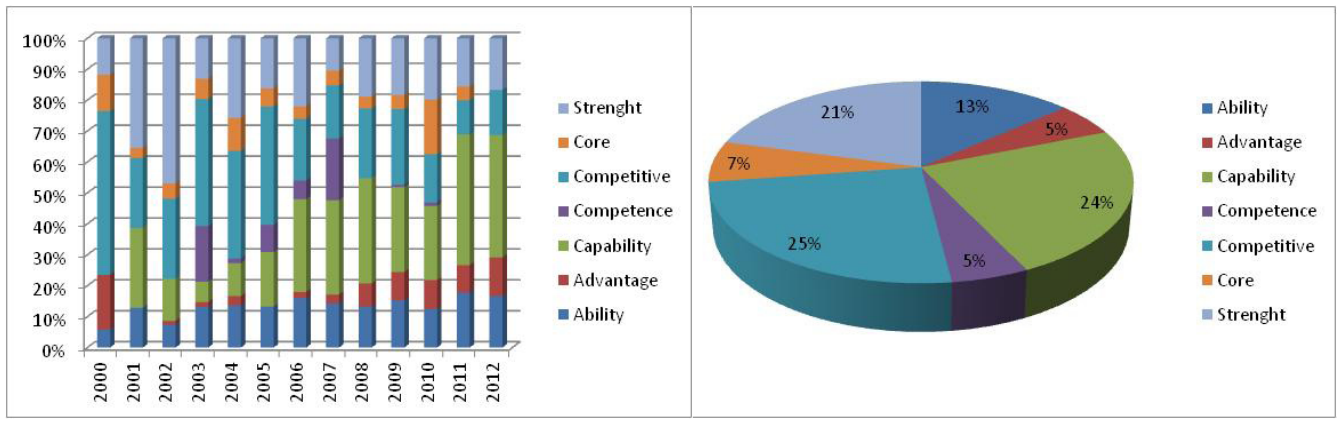

\section{Volkswagen Group}

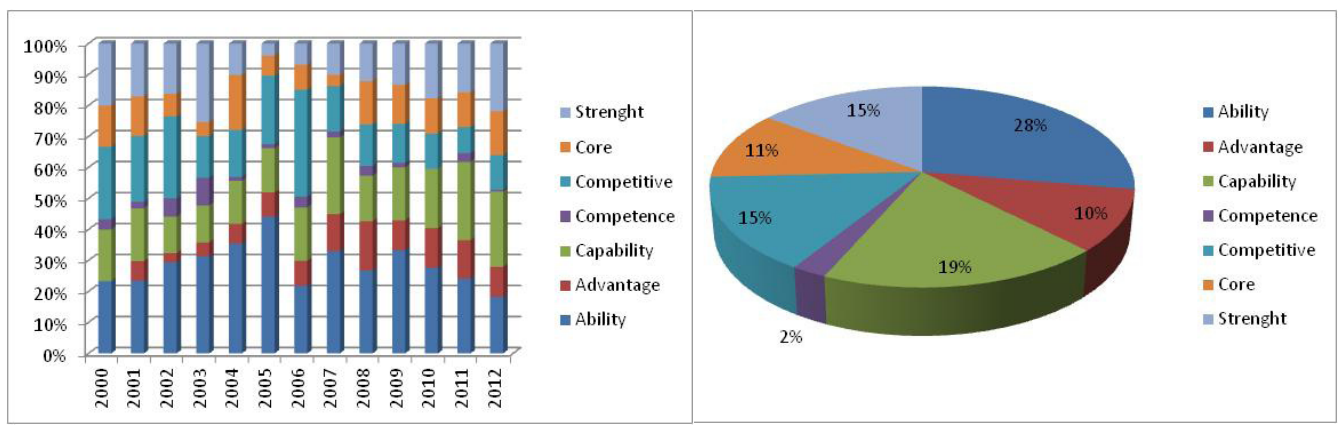

\section{BMW Group}

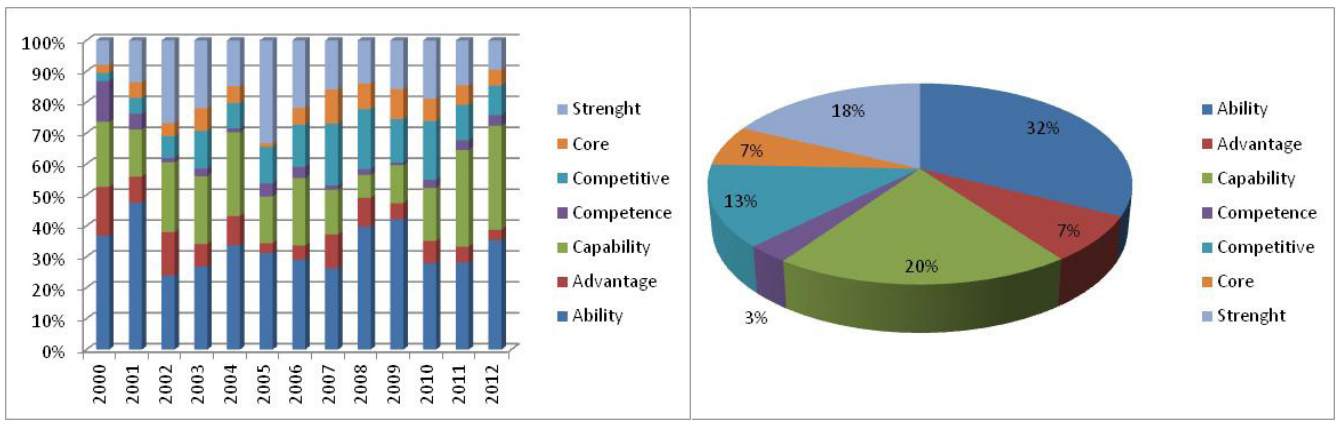

Fig. 1: Structure of the Presentation of Selected Aspects of the Competitiveness of the Evaluated Companies from the Point of Percentage Share of the Use of Particular Terms (Author) 


\section{Development of the Presentation of Selected Aspects of Competition, Cooperation and Strategic Objectives in the Period from 2000 to 2012}

The evaluation of competition has been divided into a summarizing partial term, expressing the competition as such - "competition", and a summarizing partial term of market - "market". Similarity in the behavior of the German groups there has been clearly identified a case of the term "market", expressed by the rather dramatic increase in the use of this particular term. The important fact is that terms connected with the market have been used not only for the presentation of results, but also for the identification of areas of future development. In the case of Renault this statement confirms a certain concordance in the stress on both areas in the years 2002 and 2009, when the group searched for space for its growth. Either from the viewpoint of global development in the first case, or effort for growth after the period of crisis in the second case.

Identically, similarity in the behavior of the Volkswagen Group and the BMW Group has been demonstrated in the summarizing evaluation of the assessed period from the viewpoint of co-operation. Nevertheless, gradual development has been rather different; the increase in the term "cooperation" is slow in the Volkswagen Group. The Renault Group has been different, both in summarizing structure (suppressed summarizing partial term "supply") and gradual development. The presentation of cooperation has significantly moved to the term "partner", compared to the term "cooperation".

The presentation of strategic objectives, resp. strategy as such, has shown probably the most apparent similarity in all three groups. Minimal, even negligible, has been the use of terms "vision" and "mission". The key terms in summarizing the evaluation for all groups are the terms "objective", "strategy", "success" and "target", when the terms "strategy" and "success" represent approximately $60 \%$ of the presentation. Nevertheless, the presentation of the Renault Group is radically different - approximately two thirds of this part is represented by the term "strategy", compared to approximately a half in the case of the remaining two groups. A difference may be identified also in the presentations of the groups Volkswagen and BMW. Changes in the BMW Group are more fundamental from the viewpoint of the share of "success" and "strategy" - a steady drop hand in hand with an increase in the use of the term "target". The fact is, however, that the use of the two above-mentioned terms was by far the most significant in the first evaluated year.

\section{Comparison of the Presentation of Selected Areas in the Context of the Crisis Period 2009 to 2010}

Again, a distinct difference between the Renault Group and the remaining groups can be noticed from the viewpoint of the evaluated area of competitiveness. The economic crisis has not hit too much the development of the approach which the Renault Group has presented itself, the only exception being maybe the increase in the use of the term "core". On the contrary, the Volkswagen Group and the BMW Group have changed their presentation after the period of crisis. See especially the change in the use of terms "ability", "capability", "competence" and "strength" in the pre-crisis, crisis and post-crisis period. The crisis period has been demonstrated in the area of cooperation in all three groups. The Renault Group has indicated the increase in the use of term "supply", similarly to the BMW Group. However, both groups markedly differ in the overall share of this particular term. On the contrary, the Volkswagen Group 


\section{Evaluated Area: Competitiveness}

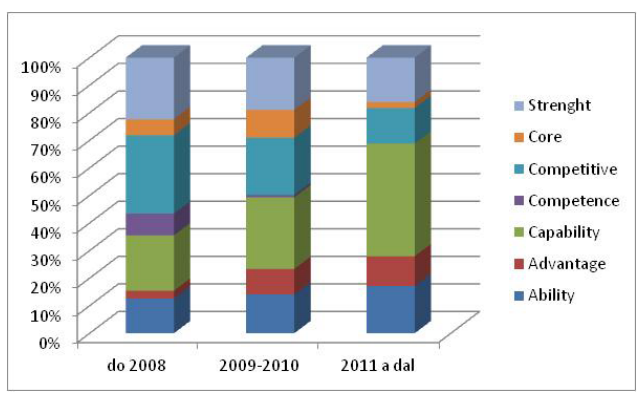

Renault Group

\section{Evaluated Area: Cooperation}

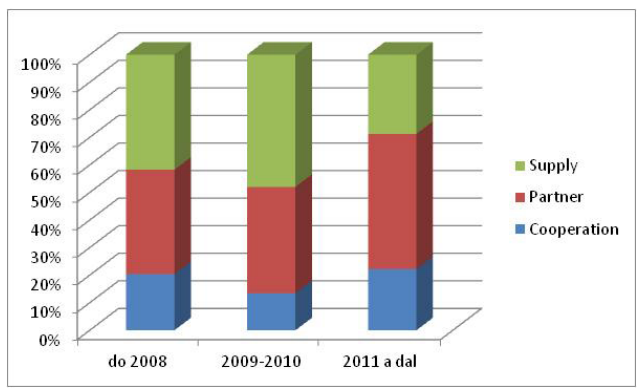

Renault Group

\section{Evaluated Area: Strategic Objectives}

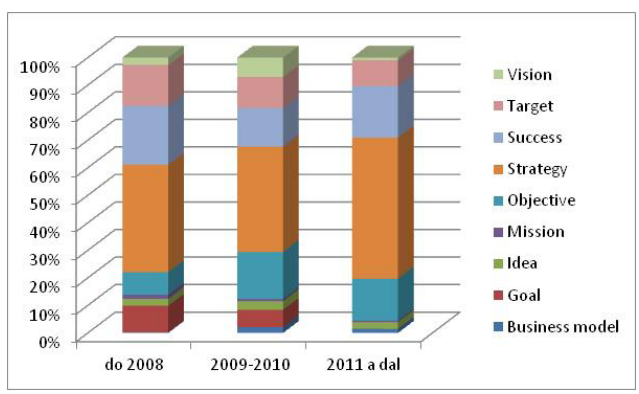

Renault Group



Volkswagen Group

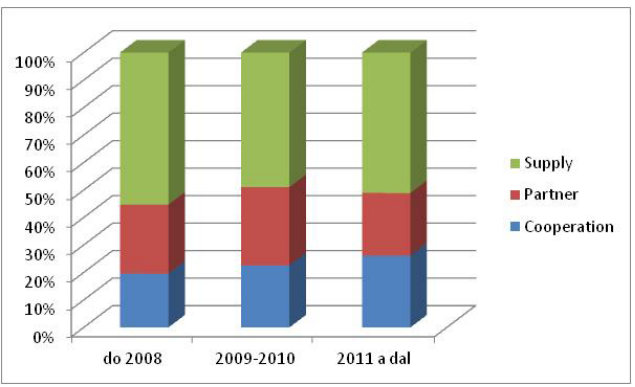

Volkswagen Group



Volkswagen Group

Fig. 2: Structure of the Presentation of Selected Areas of the Evaluated Companies in the Context of the Crisis Period 2009 - 2010 from the Point of Percentage Share of the Use of Particular Terms (Author) 


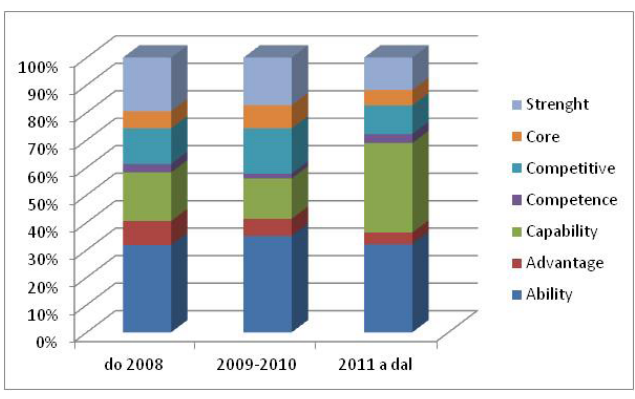

BMW Group



BMW Group

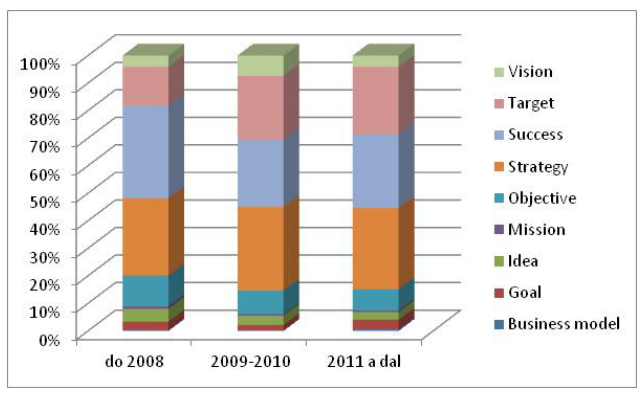

BMW Group has reported a slight suppression of this term, substituted by "partner" and "cooperation".

One common feature existing in all three groups is the massive increase in the use of certain terms characterizing objectives - in the case of the Renault Group the summarizing partial term "objective", in the case of the Volkswagen Group "goal" and in the case of the BMW Group "target”.

\section{Discussion, Limitations and Conclusions}

The compliance of both views has been apparent from the viewpoint of the evaluation of the used terminology within the framework of company practice and terminologies applied by selected theoretical concepts. A conclusion may be reached, i.e., that terminologies defined on the basis of the analysis of the three concepts of the development of competitiveness share common features, which can be clearly identified in practice. Of course, a certain risk can be faced - that practice and theory understand the content of the terms differently. As regards the spread of particular terms, such a discrepancy (if any) should not cause any serious problems. The explanatory power of the conclusions could be improved by further research into the relevant data. In principle, no less than three key approaches could be applied. The first possibility would be confronting the management of car producing companies with the results and their own evaluation of the significance of the used terms. The second possibility might be a more detailed analysis of the results and the behavior of companies in the market with the aim to compare the factual status with the used terminology and its estimated significance. A third approach might aim at customers with the objective to identify their perception of certain areas of the competitive behavior of the individual companies - namely the area of perceived advantages or perceived success could be addressed. 
The manner used by a company representing a car producing business to present its strategic behavior may be considered as a rather significant element in its general communication with its environment. Undoubtedly, this manner is significantly influenced by the character of the competitive behavior of company and, at a certain level, such a manner must reflect the approach to the strategic development of competitiveness. The specific feature of such communication is the fact that a company must communicate with various stakeholders. Usually the requirement to clearly present its behavior to owners and customers - with the simultaneous effort to hide its plans from competitors - usually clash. It is understandable that a document such as an annual report, forming the subject of content analysis, cannot include all the aspects of the strategic development of competitiveness. The extent of the use of the individual terms may be connected with the significance attributed to particular areas within the framework of the company strategy, but also with various company cultures existing in the companies or the topical popularity of a particular term.

The approach of presentation is still being developed, as is indicated in all of the evaluated groups. Such a fact is linked with the changes in their behavior as well as changes in the market. The influence of the changes in behavior may be seen in the Renault Group most significantly. In the monitored period the Renault Group developed its strategy rather dramatically and tried to find a way to guarantee its own development. On the contrary, the Volkswagen and BMW groups are "set" in a certain way and their current success is based on continuous development. Such a statement is confirmed by the identified similarity in the presentation of these groups; in spite of the fact that a similarity could be expected between the Volkswagen Group and the Renault Group considering the structure of these groups. The factor of success together with target accomplishment clearly has an influence. Such a fact is confirmed by the presentation in the area of strategic objectives, where "success" dominates in the Volkswagen Group and the BMW Group, while "strategy" dominates in the Renault Group.

The need to reach a certain level of competitiveness, enabling competition in a particular market, is reflected in the presentation of the topics of competitiveness, which - in all cases has been based on the terms "ability", "capability", "competitive" and "strength". The question is to what extent can be emphasized the ability of the Volkswagen Group and the BMW Group to better set the level of their competitiveness in the context of greater stress on the term "market". Nevertheless, the fact is that these two groups are generally evaluated as more successful. From the viewpoint of the development of competitiveness, an evident stress on co-operation aspects is clear. To a certain degree it is logical that the emphasis in the form of stress on the terms "partner" and "co-operation" is higher in the relatively less successful Renault group compared to its competitors. Such a fact can be considered as a reflection on the effort to reach resources which the company itself does not have at its disposal, and to develop them by cooperation.

The influence of market changes, not only to the approach of the presentation of companies, but above all to their actual behavior, is understandably fundamental. The evaluated influence of the crisis period is an extreme example of such an influence. The fact that the crises formed a certain turning point in the behavior prior to and after the crisis is clearly noticeable especially in the Volkswagen Group and the BMW Group. The fact that the development of the presentation of the Renault Group has been influenced less significantly may be interpreted in such a way that this particular company is searching in the long-term for setting an approach to the strategic development of competitiveness. It means that the Renault Group is forced to 
search for the optimal setting of its competitiveness in any way. The remaining groups have "only" adapted their behavior to the changed situation. The relative increase in stress on the area of objectives has been demonstrated in all three groups. Such a fact can be considered as a key finding, in particular with respect to the principles applied in the evaluation of the strategic development of competitiveness when applying the concept of success-ability. The target orientation differentiates the approaches of individual companies and justifies different approaches applied in strategic management as well as the development of competitiveness.

\section{References}

Annual reports of Renault group available at http://www.renault.com/en/pages/home.aspx the international website of Renault Group

Annual reports of BMW Group available at http://www.bmw.com/com/en/ the international BMW website

Annual reports of Volkswagen Group available at http://en.volkswagen.com/en/company.html the international Volkswagen Group website

Augier, M., 2007. Dynamic Capabilities and Multinational Enterprise: Penrosean Insights and Omissions. Management International Review. D. TEECE. 47(2), 175-192.

Collis, D. J., 1994. Research Note: How Valuable are Organizational Capabilities. Strategic Management Journal. 1994, vol. 15 , special issue, p. 143-152. ISSN:01432095.

Collis, D. J., 1997. Corporate strategy - Resources and the Scope of the Firm. $1^{\text {st }}$ ed. C. A. MONTGOMERY. McGraw-Hill. 764p. ISBN 0-256-17894-1.

De Toni, A., 2003. Strategic Planning and Firms' Competencies: Traditional Approaches and New Perspectives. International Journal of Operations \& Production Management. S. TONCHIA. vol. 23, iss. 9, p. 947-976. ISSN/ISBN: 01443577.

De Toni, A., 2003. Strategic Planning and Firms' Competencies: Traditional Approaches and New Perspectives. International Journal of Operations \& Production Management. S. TONCHIA. vol. 23, iss. 9, p. 947-976. ISSN/ISBN: 01443577.

Freiling, J. A., 2004. Competence-based Theory of the Firm. Management Revue. vol. 15, iss. 1, p. 27-52. ISSN/ISBN: 09359915.

Grant, R.M., 2008. Contemporary Strategic Analysis. $6^{\text {th }}$ ed. Blackwell Publishing. 482p. ISBN 978-1-4051-6309-5.

Hamel, G., 1996. Competing for the Future. $2^{\text {nd }}$ ed. C. K. PRAHALAD. Boston: Harvard Business School Press. 357p. ISBN 0-87584-716-1.

Hitt, M. A., 2004. Strategic Management - Competitiveness and Globalization: Concepts. ${ }^{\text {th }}$ ed. R. D. IRELAND, R. E. HOSKISSON. South-Western College Pub. 544 p. ISBN 0324275307.

Hitt, M., 2011. Relevance of Strategic Management Theory and Research for Supply Chain Management. Journal of Supply Chain Management., 47(1), p. 9-13.

Mintzberg, H., 1967. The Science of Strategy-Making. Industrial Management Review. vol. 8, iss. 2, s. 71-81.

Prieto, I. R., 2009. Building Dynamic Capabilities in Product Development: How Do Contextual Antecedents Matter? Scandinavian Journal of Management. E. B. RODRÍGUEZ-PRADO. vol. 25. iss. 3. p 313-326. ISSN 0956-5221.

Salunke, S., 2011. Towards a Model of Dynamic Capabilities in Innovation-based Competitive Strategy: Insights from Project-oriented Service Firms. Industrial Marketing Management. J. WEERAWARDENA, J. R. MCCOLL-KENNEDY. vol. 40, iss. 8, p. 1251-1263. ISSN 00198501.

Zhan, W., 2008. Performance Implications of Capability Exploitation and Upgrading in International Joint Ventures. Management International Review. Y. LUO. 48(2), p. 227-253. 
Zich, R. 2010, Koncepce úspěchuschopnosti a její pojetí strategie. E a M: Ekonomie a Management. vol. 10, n. 1, p. 60-74. ISSN: 1212-3609.

Zich, R. 2009, Strategický rozvoj konkurenčních výhod v koncepci úspěchuschopnosti ve vztahu k pojetí založeném na zdrojích a základních kompetencích. Ekonomika a Management. n. 3, p. 77-92. ISSN: $1802-8470$.

Zich, R., 2012. Koncepce úspěchuschopnosti Konkurenceschopnost - vítězství, nebo účast v soutěži? $1^{\text {st }}$ ed. Brno: Akademické nakladatelství CERM. 125p. ISBN: 978-80-7204-818- 2.

Robert Zich_Zich@fbm.vutbr.cz

Vysoké učení technické v Brně, Fakulta podnikatelská 